\title{
Current Trends on Oil Sludge Characterization, Toxicity and Treatment Systems
}

\author{
K.Suganya, C.Sivapragasam, Naresh K Sharma, S.Vanitha
}

\begin{abstract}
Oily sludge produced in the refineries contains various harmful contaminants and difficult to analyse Treatment of Petroleum Sludge is a major problem all over the world. More strict regulations are being imposed, which preservere the treatment technologies capable to deal with the hazardous pollutants. The inadvisable disposal of oil sludge leads to hazardous, due to the presence of high concentration of harmful substances. This paper presents critical review on the production, characterization, toxicity and biological treatment of petroleum sludge reported in various studies. Compared to usage and production of petroleum and oil based products, the pace of knowledge acquisition on treatment of petroleum and oil sludge is slower despite the availability of numerous treatment and remediation options. Also, the differences in performance of treatment methods and results reported from various literatures have been addressed to pave a way for a customized treatment solution to oil sludge contamination. There is a need to identify a cost effective solution through which toxic pollutants in the sludge is treated effectively with a potential to reuse as manure for cultivation of crops.
\end{abstract}

Keywords-Oil sludge, toxic pollutants; treatment methods, sludge characterization

\section{INTRODUCTION}

In India, petroleum treatment facilities by and large create roughly 20,000 tons of oily sludge per annum[1].It is additionally stated that while oil sluge generated every year amounts to more than 600 lakh tons, it is assessed that more than 10000 lakhs tons of sludge are amassed around the world[2]. A lot of petrochemical wastewater was produced in the oil refining industry and the assembling procedure of various natural synthetic compounds and crude materials, which has turned out to be a standout amongst the most difficult issues[3].The treatment of industrial sludgeis the major issue of real concern these days, increasingly exacting guidelines are being forced, which need to create and utilize the treatment innovations[4]. Safe handling of huge volumes

Revised Manuscript Received on December 05, 2019.

* Correspondence Author

Suganya K, Civil Engineering, Kalasalingam Academy of Research and Education, Tamilnadu, INDIA. Email: suganyakrishnan25@gmail.com

Sivapragasam $\mathbf{C}^{*}$, Civil Engineering, Kalasalingam Academy of Research and Education, Tamilnadu, INDIA. Email: sivapragasam@klu.ac.in

Naresh K Sharma, Biotechnology, Kalasalingam Academy of Research and Education, Tamilnadu, INDIA. Email: naresh@klu.ac.in

Vanitha S, Civil Engineering, Kalasalingam Academy of Research and Education, Tamilnadu, INDIA. Email: svanithacivil@gmail.com of sludge is a serious concern for petroleum industries. Fig .1 Shows the process unit of petroleum sludge generation and its treatment methods.

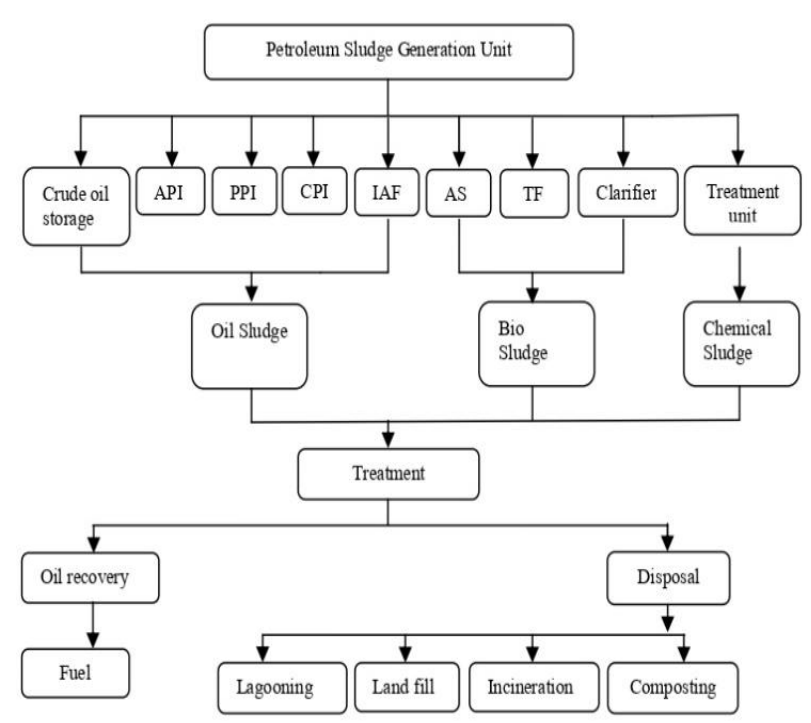

API - Americal Petroleum Institue Separator

PPI - Parallel Plate Interceptor

CPI - Corrugated Plate Interceptor

IAF - Induced Air Flotation Unit

TF - Trickling Filter

AS - Activated Sludge

Fig.1.Flow chart -Petroleum sludge generation unit

Oily sludge in considerable amount is one of the by-products from the petroleum refineries which is typically composed of water, metals, suspended soilds and hydrocarbon. Petrochemicals, sometimes petroleum chemicals, can be described as any chemicals which are derived from petroleum or natural gas. Major challenge is posed by the waste oil in both the wastewater treatment and in the petroleum sludge treatment techniques. High oil substance rich petroleum sludge would devour increasingly synthetic conditioners [5]. In the most demanding issues concerning environmental studies, under the present scenario, the issue of sludge management stands out with associated high expenses [6]. This demands a paradigm shift by bringing in more robust methods for processing of petrochemical sludge and its utilization. Treatment technologies studied by the researchers for the biological treatment of petroleum refinery sludge include lagooning, landfilling, incineration and composting. After pre-treatment of oil sludge, the land treatment is reported to be the most appropriate method ([7-8]). Oil Sludge comprise of waste water, oil waste and mineral particles [9]. 
As per Environmental Protection Agency (EPA) regulation, sludge is classified as hazardous and toxic waste which are differentiated as chemical, oily and bio sludge [10]. Particularly, oily sludge has been classified as hazardous substances [11] because it contains significant amount of petroleum hydrocarbons (PHCS) [14]. Oil storage tanks and refinery wastewater treatment plants are believed to be the two major sources of oil sludge [12]. Sludge is usually found to accumulate in refinieries under conditions such as draining of oil from tanks, draining of oil from operation units, failure of pumps, ruptures in pipe lines and maintenance activity involving the cleaning of storage tanks [13]. There are various treatment techniques, this review investigates on characteristic of oily sludge, process and identification of suitable solution for treatment of oily sludge waste. Fig.2 shows the increase in generation of refinery outputs in countries all over the world.

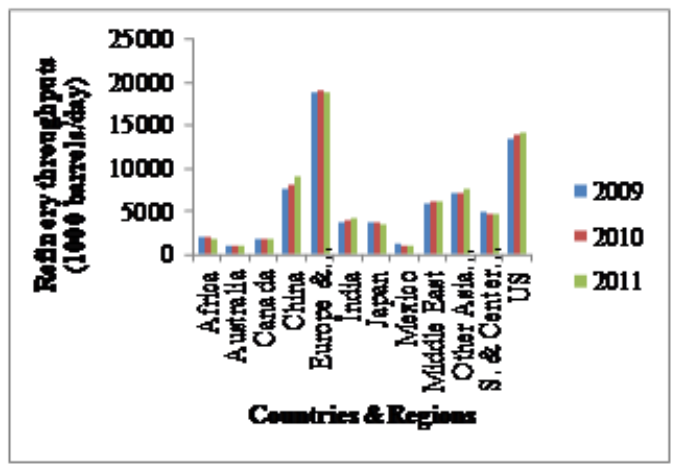

Fig.2.Refining throughputs-worldwide

a) Toxicity of Oily sludge

Due to the presence of high fixation poisonous substances, the inappropriate transfer of oil sludge can cause threats to the acquiring habitat. Consequent to entering the earthly condition, the physical and chemical properties of accepting soils can be distressed by the oil sludge, thereby prompting soil morphological change [14]. Fig.3 shows various impact of oil sludge. When the oily sludge is disposed to the environment without proper treatment, the presence of poly aromatic hydrocarbons (PAHs) and heavy metals can lead to various toxic effects [2].

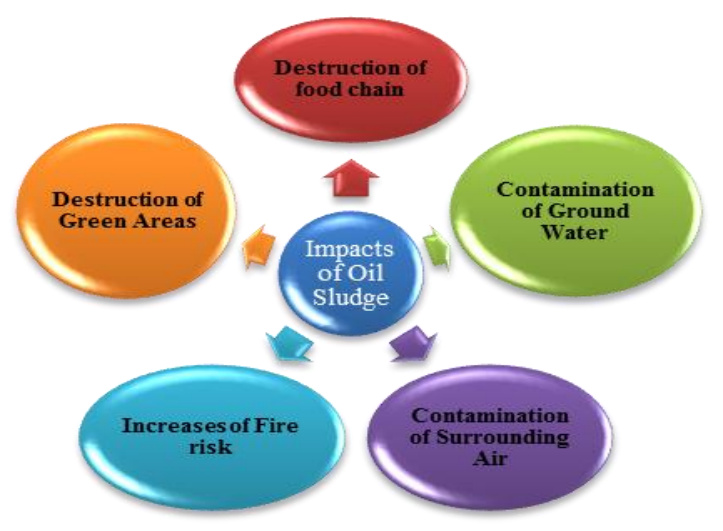

Fig.3.Various impacts of oily sludge

b) Characteristic of oily sludge
Ubani et al., [1] described how the composition of oily sludge differs due to the raw materials used in the manufacturing of crude oil and the process used for the oil water separation. Robertson et al., [14] reported that petrochemical sludge contains oil, metal salt, sulphide, volatile phenol and other substances apart from nitrogen and phosphorus. Fig.4 shows the basic composition of oily sludge. The petroleum sludge usually contains propane, hydrocarbons, ethane, methane, butane, and various aromatic hydrocarbons and organic compounds like Sulfur Nitrogen, Oxygen, and pinch amount of metals such as Vanadium, Nickel, Iron and Copper. In summary, it is seen that oil sluge mainly comprises of alkanes, aromatics, alphaltenes and resin with composition of oil and solids typically as $80 \%$ and $20 \%$ respectively [16].

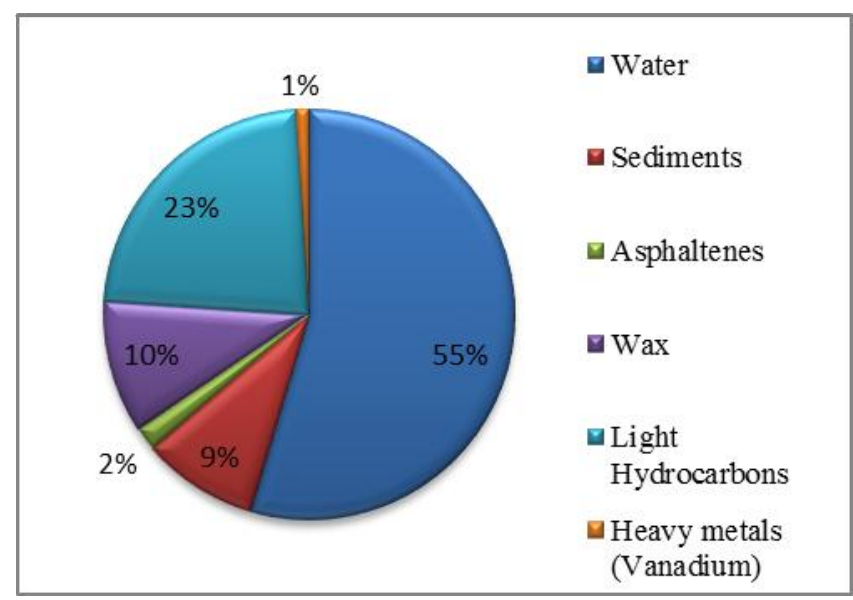

Fig.4.Basic composition of oil sludge

TABLE I: TOXIC POLLUTANTS PRESENT IN OILY SLUDGE

\begin{tabular}{|l|l|l|}
\hline S.no & $\begin{array}{l}\text { Toxic Pollutants present in oil } \\
\text { Sludge }\end{array}$ & $\begin{array}{l}\text { Reference } \\
\text { S }\end{array}$ \\
\hline 1. & $\begin{array}{l}\text { Asphaltenes, Alkanes, Resin and } \\
\text { Aeromatics }\end{array}$ & {$[16]$} \\
\hline 2. & $\begin{array}{l}\text { Semivolatile organic } \\
\text { carbons(SVOCS) and Volatile organic } \\
\text { Carbons(VOC } \text { ) }\end{array}$ & {$[17],[18]$} \\
\hline 3. & $\begin{array}{l}\text { Anthanthrene, Fluoranthene, } \\
\text { Acenapthylene, Naphthalene } \\
\text { Phenanthrene, Benzo[a] } \\
\text { anthrancene,Benzo[ghi]perylene.,Ben } \\
\text { zofluoranthenes,Benzopyrenes, }\end{array}$ & {$[19]$} \\
\hline 4. & $\begin{array}{l}\text { Poly Aromatic Hydrocarbon(PAHs) } \\
5 .\end{array}$ & $\begin{array}{l}\text { Pyrene,Dibenzo(a,h)anthracene,Benz } \\
\text { o(ghi)perylene,Fluorene,Phenamthren } \\
\text { e,Anthracene,Fluoranthene,Pyrene,Be } \\
\text { nzo(b)fluoranthene,Benzo(k)fluorant } \\
\text { hene,Benzo(a)Pyrene,Indeno(1,2,3-cd } \\
\text { ),Naphthalene,Acenaphthylene,Acena } \\
\text { phthene }\end{array}$ \\
\hline
\end{tabular}

\section{OIL SLUDGE TREATMENT METHODS}

Petrochemical sludge is considered to be complex combination of various organic and inorganic compounds and difficult to dispose without proper treatment to the environment. In fact, improper treatment and refining of such sludge could be potentially highly dangerous to the environment which is a growing concern all over the world [23].

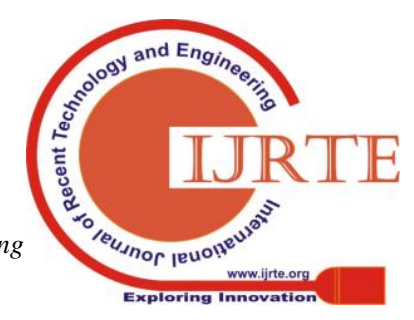


Kripsalu et al., [22] investigated that biological treatment is the utilization of microbial digestion of organic matter and making the pollutants as harmless. One of the by-products of the biological treatment process is the production of excess sludge which adds to serious issue in the treatment of wastewater. The production of such sludge may even account for even $60 \%$ of total associated cost and energy demands. These factors need to be taken into consideration while choosing the biological process for treatment. [24], [25] reported that techniques such as bioreactor, land farming, composting, etc., are very much effective for the degradation of PAHs in soil

The various treatments of oil sludge includes,

\section{1) Lagoon / Pit}

Although use of cement and brick lined lagoons are scientifically proven methods for discarding oily sludge, the associated problems such as that of odour and fire hazards cannot be neglected [26]. Such method of deposition of refinery oily sludge is also identified to contribute to the atmospheric volatile organic compounds (VOCs) [27]. Minimum studies are reported in the lagooning treatment and this technique should be adopted with caution as it will tend to emerge various toxic gases.

\section{2) Incineration}

Incineration is a technique used for the process of burning of oily waste within the sight of abudance air and fuel,and it is generally accepted as an effective method in many processing plants for sludge treatment, and more particularly in refineries. However, the associated problem involves production of $\mathrm{CaO}, \mathrm{SiO}_{2}$ and $\mathrm{MgO}$ from such incineration of the sludge. These oxides are found to have the same physical properties as powedered minerals. [6] and [28] found that the cost effectivenss of the incineration process is as function of weather condition. Hu et al., [13] and Hung et al., [31] reported that the oily sludge contains substances that are resistant to combustion process and are present in high concentration which in turn will end up in high operating and capital cost. From the advantage point of view, burning of sludge in incinerator can be valuable energy sources which can result in cost effectiveness by using this energy for driving steam turbnines in a waste oil reclamation industry. It should be noted that, however, such energy recovery can be done at the cost of evolving of toxic gases in the process [27]. Vesilind [32] reported that oily sludge with excess dampness should be pretreated to improve its ecofriendliness. Another reported advantage in this process is considerable reduction in volume and improved energy efficiency [33]. Incineration process requires high capital and operating cost and the incomplete combustion would cause atmospheric pollution.

\section{3) Landfilling}

Due to the rigidity in environmental protection and control regulations by almost all the government bodies as well as due to scarcity of land, landfilling may no longer be a preferred technique for sludge disposal [32]. Jacques et al., [20] reported the pseudomonas isolates may be effective for PAHs degradation. Demastas et al., [33] stated that cement and fly ash have been accounted for a satisfactory choices to treat and anticipate draining of substantial metals sorted as lethal and unsafe. The prevailing humid conditions in a landfill will lead to decrease in incineration efficiency with increase in dampness of the waste mass [6]. Bhattacharya et al., [26] found that land farming treatment cost is much higher and hence, in many countries like Taiwan, landfill treatment is limited by both cost and space [33].The various impacts of landfilling site are,

1. Surface and groundwater pollution due to leaching of pollutant and surface runoff.

2. Emission of polluting gases like $\mathrm{CH}_{4}, \mathrm{H}_{2} \mathrm{~S}$ etc.

3. Changes in soil characteristic and texture.

4. $\quad$ Fire and Health Hazard

5. Decrease in land value.

6. Effect on natural vegetation and plant growth.

\section{4) Composting}

Variuos works have been described the use of composting for the treatment of refinery oil sludge. Hu et. al., [2] reported that composting of oil sludge has earned enlarged consideration as alternate innovation for land cultivation which frequently requires a huge land zone. The term 'Biopile' is commonly used to refer to transforming of waste materials into piles of 2 to $4 \mathrm{~m}$ height which can be subject to degradation by microorganisms - both indigenous or extraneous. Compared to composting for bioremediation, which has not received wide acceptance, the physical, chemical and biological methods are neither cost effective not environment friendly [35]. Sergvi et. al., [36] found that due to the addition of phosphate fertilizer that lead in oily sludge will get reduced. Ling et al., [37] reported that, over a 9 weeks study period, contaminated soil added to sewage sludge has resulted in a maximum removal of $65.6 \%$ of oil and grease. Milne et al., [38] found that hydrocarbon removal can be enhanced by addition of plant material soil. Chang et al., [39] found that about $55 \%$ reduction of TPH was achieved by using solv-II as a bulking agent/nutrient source when compared to heat treated peat moss and barley straw both of which ended up with a maximum of $30 \%$ reduction. Piskonen et al., [40] reported that biostimulation, a process by which nutrients are added to stimulate either growth or degradative ability of indegeneous microorganisms, can increase the availability of hydrocarbons present in the oily sludge and thus improve the biodegradation process of oil sludge.

\section{RESEARCH GAP}

Growing interest has been seen in the development of efficient, economic and environment friendly means of processing of oily sludge. Many technologies have been developed all over the world like advanced oxidation treatment but its reaction end products are usually more biodegradable, but when treating the large volume of oily sludge, the oxidation may require a large amount of chemical reagents. However currently it is difficult to identify one single method or set of methods which are most successful. Sludge disposal methods like lagooning, landfilling, incineration and composting which are discussed in this study shows that it takes more time to degrade the oily sludge. On the other hand, incineration and landfilling can cause environmental pollution and leachate formation which should be taken into consideration while choosing these methods. Many studies reported that these two methods are less efficient. Bioremediation process can be implemented in composting by Rapid composter-bioreactor 


\section{IV.CONCLUSION}

Petroleum and oil refinery sludge produces very toxic effect to the environment. The various compounds contained in the oily sludge and their toxic effects have been discussed. This study gives insights in to various disposal and treatment methods of oily sludge along with their advantages and limitations. The physical and chemical methods require extensive usage of chemicals which may produce toxic secondary sludge while the bioremediation process can be implemented to reduce the decomposition rate time. Although the bioreactors can be introduced to avoid the foul and toxicity of the sludge to reuse eco-friendly manure, there are a few challenges in identifying and acclimatizing suitable microbes for effective treatment. There is a major gap in designing engineered biosystems customized for oil sludge bioconversion to organic manure.

\section{REFERENCES:}

1. Badrullslam, “'Petroleumsludge, itstreatment”,Int.J.Chem..Sci:13(4),2 015,1584-1602,2015

2. Guangji Hu ,Jianbing Li, and Guangming Zeng, “'Recent development in the treatment of oily sludge from petroleum industry-A Review”,Journal of Hazardous Material,2013

3. Q Yang,P Xiong,P Ding,L chu, "Treatment of petrochemical wastewater by microaerobic hydrolysis and anoxic/oxic processes and analysis of bacterial diversity",Biosource Technology",2015

4. Diaz, "System for treating petroleum and petrochemical slop oik and sludge waste",2007

5. N.Buyukkamaci,E.Kucukselek, "Improvement of dewatering capacity of a petrochemical sludge,J.Hazard.,2015

6. M.Pazoki, B.Hasanidarabadi, "Management of toxic and hazardous contents of oil sludge in Siri Island,"Global J.Environ.sci.Manage,2017

7. M.Pazoki,M.A.Abdoli,M.A.Karbasi,N.Mehrdadi.N.Yaghmaeian,K.S alajegheh "Removal of nitrogen and phosphorous from municipal landfill leachate through the land treatment.World Appl.Sci.J.20(4):512-519,8 pages,2012

8. M.Pazoki,M.A.Abdoli,M.A.Karbasi,N.Mehrdadi.N.Yaghmaeian, "Attenuation of municipal landfill leachate through land treatment,J.Environ.Health Sci.Eng.,12(12):1-6(6pages),2014

9. Shilipi Verma, Basheshwar Prasad, Indra Mani Mishra, "Pretreatment of Petrochemical Wastewater by coagulation and flocculation and sludge characteristics", Journal of Hazardous Materials 178(2010)1055-1064,2010.

10. EPA,Safe,environmentally acceptable resources recovery from oil refinery sludge,U.S Environmental Protection Agency(EPA),Washington DC,1991.

11. O.Ubani,H.L.Thantsha,M.S, “Biological degradation of oily sludge:a review of the current state of development.Afr. J. Biotechnol 12(47),6544-6567,2013

12. J Shie, J Lin, C Chang, $\mathrm{C}$ Wu ,D Lee, "'Oxidative thermal treatment of oil sludge at low heating rates", Energy Fuel 18:1272-1281,2004.

13. Guangji Hu Jianbing Li Guangming Zeng, "Recent Development in the treatment of oily sludge from Petroleum Industry",Journal of Hazardous Materials,2013.

14. S.J.Robertson,W.B.MCGill,H.B.Massicotte,P.M.Rutherford, "Petroleum hydrocarbon contamination in boreal forest soils:a mycorrhizal ecosystems perspective,Biol.Rev.82 213-240,2007

15. H.M.Zhang,He,Y.L.Jiang,F.Yang, "Research on characteristic of aerobic granules treating petrochemical wastewater by acclimation and co-metabolism methods,Desali nation 279(1-3),69-74,2011.

16. M Diallo ,JLCagin T,Faulon ,Goddard WA, “Thermodynamic properties of asphaltene:A predictive approach based on computer assisted structure elucidated and atomistic simulations",In:Yen TF,Chilingarian GV (eds) Asphaltene and Asphalts II,developments in Petroleum Science 40B,Elsevier Amsterdam,103-127,2000.

17. S.Mishra, J.Jyot, R.C Kuhad,B.Lal,“In situ bioremediation potential of an oily sludge-degrading bacterial consortium.Curr Microbial $43: 328-335,2001$

18. Q.D Bach,S.J Kim,S.C Choi,Y.S Oh, "Enhancing the intrinsic bioremediation of PAH-contaminated anoxic estuatine sediments with biostimulating agents.J Microbiol 43:319-324,2005

19. A.Dominguez, J.A.Menendez, M.Inguanzo, P.L.Bernad, J.J.Pis, “Gas Chromatographic-mass spectrometric study of the oil fractions produced by microwave-assisted pyrolysis of different sewage sludge.J Chromatogr A 1012:193-206,2003

20. Rodrigo Jacques, Eder Santos,Fatima Bento , "Anthracene Biodegradation by Pseudomonas sp.isolated from a Petrochemical sludge landfarming site",International Biodeterioration\&Biodegradation 56(2005) 143-150,2005

21. Otidene Rossiter sa da Rocha,Renato F.Dantas,Marta Maria Menezes B.Duartte,Marcia Maria Lima Duarte,Valdinete Lins da silva, "Oil sludge treatment by photocatalysis applying black and white light",Chemical Engineering Journal 80-85,2010

22. M. Kriipsalu, M.Marques, M.Nammari, D.R.William, "Hazard.Mater. 148,616-622, 2007

23. O.R.S Da Rocha,R.F Dantas,M.M.M.B,Duarte M.M.L,V.L Da Silva, "Oil Sludge treatment by photocatalysis applying black and white light,Chem.Eng. J.,157(1).80-85,2010.

24. Zhu Wei, "Analysis and Performance mensuration of pyrolysis products for oil sludge",Environmental Chemistrty,2010

25. A.Gibb, Rck Wong, RH Goodman, "Bioremediation Kinetics of Crude

26. J.K.Bhattacharyya,A.V.Shekdar, "Treatment and disposal of refinery sludge: Indian Scenario", Waste Management \&Research 21:249-261,2003.

27. N.P.Cheremisinoff,P.Rosefeld, "Chapter 1:The petroleum Industry,in: Handbook of Pollution Prevention and cleaner Production - Best Practices in the Petroleum Industry",William Andrew Publishing,Oxford,pp 1-97,2009.

28. H.Belevi,M.Langmeier, "Factors determining the element behaviour in municipal solid waste incinerators.2.Laboratory experiments.Environ.sci.Technol.34,2507-2512,2000

29. H.Shiva, "A new electrokinetic technology for revitation of oily sludge, in: The Department of building,civil and Environmental Engineering,Concordia University, Montreal, Quebec, Canada,pp.29,2004

30. A.Al.Futaisi, A.Jamrah, B.Yaghi, R.Taha, "Assessment of alternative management techniques of tank bottom petroleum sludge in oman,J.Hazard .Mater,141(2007)557-564,2007

31. Hung-Lung Chiang, Ching-Guan Chao,C.Y.Chang, C.F.Wang,P.c.Chiang, "Residue characterstics and pore development of Petrochemical Industry sludge Pyrolysis",Wat.Res.Vol.35,No.18,pp.4331-4338,2001

32. P.A Vesilind, "Treatment and disposal of wastewater sludges",Ann Arbor Science,Michigan,1979

33. D.Dermatas, X.Meng, "Utilization of fly ash for stabilization/solidification of heavy metal contaminated soils.Eng.Geol.,70(304):377-394,2003

34. Hung-Lung Chiang, Ching-Guan Choa, Shin-yu Chen,Mu-Chuan Tsai, "The Reuse of Biosludge as an adsorbent from a Petrochemical Wastewater Treatment Plant',Journal of the Air \&waste Management Association, Volume 53,2003

35. Ved Prakash,Sarika Sakena,Ambika Sharma,Sweta singh,Sunil Kumar Singh, "Treatment of oil sludge contamination by composting",Journal Bioremediation \&Biodegradation,2015

36. Sergyi Vdovenko,Sergyi Boichenko,Victoria Kochubel, "Composition and Properties of Petroleum Sludge Produced at the refineries",Chemistry\&Chemical technology,Vol.9,No.2,2015

37. Chua Choon Ling , Mohamed Hasnain Isa, "Bioremediation of oil sludge contaminated soil by co-composting with sewage sludge',Journal of scientific\& Industrial Research,Vol.65,pp.364-369,April 2006

38. Zhi-Zhou Chang, Richard W.Weaver, "Organic Bulking Agents for Enhancing oil Bioremediation in soil",,Department of soil and crop science,Texas a\$m University,College station,TX,77843-2474,Apr 2008.

39. B.J.Milne, H.R.Baheri and G.A.Hill, "Composting of a Heavy oil Refinery Sludge",110 science palce,Saskatoon,sk,Canada S7N 5 C9, 1998 .

40. R.Piskonen,M.Itavaara, "Evaluation of chemical pretreatment of contaminated soil for improved PAH bioremdiation",Appl Microbial Biotechnol 65:627-634,2004 
41. APHA, "Standard methods for the examination of water and wastewatetr, $20^{\text {th }}$ ed.American Public Health Association/American Water Works Association/Water Environment Federation,Washington,DC,USA, 1998

42. Metcalf Eddy, "Wastewater Engineering: Treatment and Reuse", $4^{\text {th }}$ ed.,Tata McGraw-Hill Publication,New Delhi,2003,pp.478-479.

43. American Petroleum Institute, "Manual on disposal of refinery wastes.Volume on solid waste.API,Newyork,Chap 7,pp 1-3.

44. G.L.Jing,M.M.Luan,T.T.Chen,C.J.Han, "An effective process for removing organic compounds from oily sludge",J.Korean Chem.Soc.,55,842-845,2011

\section{AUTHORS PROFILE}

Suganya $\mathbf{K}$ is currently a $\mathrm{PhD}$ scholar in the Department of Civil Engineering at Kalasalingam Academy of Research and Education. Her research topic is on genetic programming of biological systems for waste treatment.

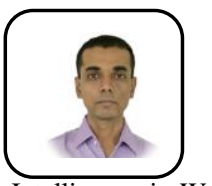

Sivapragasam $\mathbf{C}$ is a Professor in Department of Civil Engineering, Kalasalingam Academy of Research and Education. He completed his PhD from NUS Singapore and has published several papers in the area of Artificial Intelligence in Water resources, Genetic Programming and Hydraulics. His h-index and $i 10$ index are 11 and 12 respectively.

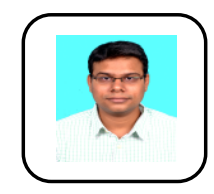

Naresh Kumar Sharma is an Associate Professor at Kalasalingam Academy of Research and Education in Department of Biotechnology. He completed his PhD from IIT Madras. His research interests include bioremediation and wastewater treatment.

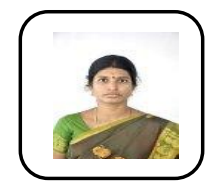

Vanitha $\mathbf{S}$ is an Associate Professor in Department of Civil Engineering, Kalasalingam Academy of Research and Education. She completed her $\mathrm{PhD}$ in the area of Genetic Programming and environmental engineering. Her h-index and i10 index are 4 and 1 respectively. 